\title{
Evaluation of Common Wheat Stubbles (Triticum aestivum L.) for Pulp and Paper Production
}

\section{Procjena mogućnosti upotrebe strnjike obične pšenice (Triticum aestivum L.) za proizvodnju celuloze i papira}

\author{
Original scientific paper • Izvorni znanstveni rad \\ Received-prispjelo: 12. 1. 2016. \\ Accepted-prihvaćeno: 5. 5. 2016. \\ UDK: $630 * 861.069 ; 630 * 862.1$ \\ doi:10.5552/drind.2016.1603
}

\begin{abstract}
The aim of the study was to determine the properties of pulp and paper produced from wheat stubble (Triticum aestivum L.), using soda-oxygen-sodium borohydride (NaBH $)$ cooking method. Whole wheat straw (Triticum aestivum L.) was also used for comparison with stubbles. The morphological and chemical properties of the raw materials were investigated. The results showed that stubble had high holocellulose, cellulose, and alpha-cellulose contents and low lignin content. Fiber length, fiber width, lumen diameter, and cell wall thickness were measured in order to determine suitability of the fibers for pulp and paper production. The values were used to calculate fiber parameters. The effects of these parameters on paper strength were also discussed. The effect of $\mathrm{NaBH}_{4}$ on the yield and chemical, physical, and optical properties of pulp and paper were investigated. The addition of $\mathrm{NaBH}_{4}$ increased pulp yield by $4.1 \%$, and improved the physical and optical properties of the pulp. The physical and optical properties of the stubble pulp were better than those of whole wheat straw pulp. It was concluded that these characteristics demonstrate the suitability of wheat stubbles for pulp and paper production.
\end{abstract}

Key words: stubble, wheat straw, soda-oxygen, pulp, paper, sodium borohydride

\begin{abstract}
SAŽETAK • Cilj istraživanja bio je odrediti svojstva celuloze i papira proizvedenih od strnjike pšenice (Triticum aestivum L.) metodom kuhanja s dodatkom soda-kisik-natrijborohidrida (NaBH4). Radi usporedbe, određena su i svojstva celuloze i papira izrađenih od slame pšenice (Triticum aestivum L.). Određena su i analizirana morfološka i kemijska svojstva istraživanih sirovina. Rezultati istraživanja pokazali su da strnjika pšenice ima visok sadržaj holoceluloze, celuloze i $\alpha$-celuloze te nizak sadržaj lignina. Radi utvrđivanja prikladnosti vlakanaca za proizvodnju celuloze i papira, izmjereni su duljina vlakanaca, širina vlakanaca, promjer pora i debljina stanične stijenke. Dobivene su vrijednosti iskorištene za izračun parametara vlakanaca. Također je analiziran utjecaj tih parametara na čvrstoću papira. Istražen je utjecaj $\mathrm{NaBH}_{4}$ na prinos celuloze te na kemijska, fizikalna i optička svojstva celuloze i papira. Dodatak $\mathrm{NaBH}_{4}$ povećao je prinos celuloze za 4,1\% i poboljšao fizikalna i optička svojstva celuloze. Fizikalna i optička svojstva celuloze izrađene od strnjike pšenice bila su bolja od svojstava celuloze proizvedene od pšenične slame. Zaključeno je da svojstva celuloze proizvedene od strnjike pšenice potvrđuju pogodnost te sirovine za proizvodnju celuloze i papira.
\end{abstract}

Ključne riječi: strnjika, p̌̌enična slama, soda-kisik, celuloza, papir, natrijev borohidrid

\footnotetext{
Authors are professor and assistant at Forest Industry Engineering Department, Faculty of Forestry, KSU, Kahramanmaras, Turkey.

Autori su profesor i asistent Odsjeka za industrijsku preradu drva, Šumarski fakultet, KSU, Kahramanmaras, Turska.
} 


\section{INTRODUCTION}

\section{UVOD}

Shortage of raw materials for pulp and paper production has led paper-makers to find new raw material resources. Several studies have been carried out in order to discover these resources. Annual plants and agricultural wastes are supplement to wood-based raw materials for pulp and paper production. Lignocellulosic annual plants have been used in pulp and paper production as early as the $19^{\text {th }}$ century. Due to greater pulp and paper production, the need for annual plants showed a rapid increase especially after the Second World War and many small and large-scale mills were established for the pulp and paper production from annual plants (Eroglu, 1983; Tutus, 2000; Akgul,2007).

Agricultural residuals have an important place in terms of potential production within the world and are one of the most important raw materials that could be utilized in the pulp and paper industry (Cheng, 1993). Also, agricultural waste or pruning support more organisms than living plants (Paul and Clark, 1989). These organisms infect the future cereals. For this reason, stubble should be converted to more beneficial products. Gencer (2015) reported that paper of standard quality could be made from kiwi pruning.

In general, pulping of non-woods is easier compared to wood. Non-woods have low lignin content and, therefore, require fewer chemicals during cooking, where the raw material is chemically treated under high temperature and pressure to separate lignin from the fibers. Although kraft or sulfate is the preferred pulping procedure for wood, non-woods are generally cooked by soda and sulfite as well as sulfate processes (Chandra, 1998).

Stubble is defined as short stalks, which are left standing in fields after wheat or other cereal crops have been harvested. Stubble remaining in the soil after harvest of grain is a source of organic substances. Unfortunately, it is usually burned after harvest in Turkey (Sahinbas, 2015).

Burning stubble:

- destroys organic substances,

- makes land sensitive to water and wind erosion,

- creates smoke that causes air pollution but also traffic accidents,

- causes land to be infertile.

The fire decreases the clay ratio of the soil and reduces the capacity of water absorption and ratio of plant nutrients (Kara and Bolat, 2009).

Stubble can be an important raw material for pulp and paper production. Stubble height for the cereal straws is about $18-20 \mathrm{~cm}$. The harvest index of wheat straw is about $1 / 2.66$ (seed/straw). This index is reduced to $1 / 1.81$ (seed/straw) with collecting and transportation losses. This ratio can change depending on stubble height and transportation conditions (Tutus et al., 2009). According to this rate, in 2014, world and Turkey stubble amounts were 605.3 and 16.2 million tonnes, respectively (Faostat, 2015). Due to the lignocellulosic fiber structure, wheat straws are used in paper and board, composite materials, and animal feeding industries (Aksoy et al., 2014).
Turkey, as one of the major cereal producers in the world, has the potential to produce a significant amount of wheat straw. In this study, the chemical, physical and optical properties of stubble treated with soda-oxygen- $\mathrm{NaBH}_{4}$ were studied.

\section{MATERIAL AND METHODS} 2. MATERIJAL I METODE

\subsection{Materials}

2.1. Materijali

This study was performed at the Kahramanmaras Sutcu Imam University Faculty of Forestry, Pulp and Paper Production Laboratory. The raw materials used in this study were harvested from KahramanmarasTurkey at the end of the growing season.

\subsection{Chemical analysis and fiber properties}

\subsection{Kemijska analiza i svojstva vlakanaca}

The raw materials were analyzed for $\alpha$-cellulose, lignin, ash and water contents, and $\mathrm{NaOH}(1 \%)$ solubilities using TAPPI Standard Tests Methods (1992). Extractives were measured using the ASTM standard procedures (2013). The holocellulose and cellulose contents were determined according to Wise's (1962) chlorite and Kurschner-Hoffer (1993) nitric acid method, respectively. Fiber length and width, lumen diameter, and cell wall thickness of the raw material were measured with a microscope. To measure the fiber morphologic properties of the specimens $(0.5 \mathrm{~mm}$ thick and $2 \mathrm{~cm}$ long in parallel to fiber), the chloride method was applied. In this method, specimens were immersed into chloride solution until they were defibered and measurements were done with an Olympus BX51 microscope.

\subsection{Pulping procedure \\ 2.3. Priprema celuloze}

Air dried samples were cut into pieces about 6 $\mathrm{cm}$ long. 12 cooking experiments were performed on stubbles, using soda-oxygen- $\mathrm{NaBH}_{4}$ processes to determine the optimum pulping conditions (Table 1). The optimum conditions were also performed on whole wheat straw for comparison.

Cooking experiments were conducted in an electrically-heated rotary digester of $15 \mathrm{~L}$ capacity, and 25 $\mathrm{kg} \cdot \mathrm{cm}^{-2}$ maximum pressure. All pulps were washed and screened on a $0.15 \mathrm{~mm}$ slotted screen. The screened pulp yields and screen rejects are also presented.

Viscosity measurement of pulp plays an important role in identifying the characteristics of the pulp such as polymerization degree or cellulose chain length (Yasar et al., 2016), while the kappa number is an indication of the residual lignin content or bleachability of pulp. Viscosity and kappa number of the pulp were measured according to TAPPI T 230 om-08 and TAPPI T 236 om-13, respectively. The screened pulp was beaten in the hollander beater to $50 \pm 3{ }^{\circ} \mathrm{SR}$ (Schopper Riegler) freeness level according to Tappi T 200 sp-96 and ten handsheets per tested sequence with grammages of $70 \mathrm{~g} \cdot \mathrm{m}^{-2}$ were prepared using a Rapid-Kothen 
Table 1 Pulping conditions of stubbles

Tablica 1. Uvjeti pripreme celuloze od strnjike pšenice

\begin{tabular}{|l|c|c|}
\hline Pulping conditions/ Uvjeti pripreme celuloze & Unit / Jedinica & Value / Vrijednost \\
\hline $\mathrm{NaOH}$ charge / udjel $\mathrm{NaOH}$ & $\%$ & 16 \\
\hline $\mathrm{NaBH}_{4}$ charge / udjel $\mathrm{NaBH}$ & $\%$ & $0,0.1,0.3,0.5$ \\
\hline Oxygen pressure / tlak kisika & $\mathrm{Bar}$ & 7 \\
\hline Cooking temperature / temperatura kuhanja & ${ }^{\circ} \mathrm{C}$ & 140 \\
\hline Time to maximum temperature / vrijeme do postizanja maksimalne temperature & $\mathrm{min}$ & 40 \\
\hline Time at maximum temperature / vrijeme pri maksimalnoj temperaturi & $\mathrm{min}$ & 50 \\
\hline Liquor to raw material ratio / omjer otapala i sirovine & $\mathrm{L} / \mathrm{kg}$ & $5 / 1$ \\
\hline
\end{tabular}

sheet former according to ISO 5269/2. Breaking length (TAPPI T 494 om-01), burst index (TAPPI T 403 om2), tear index (TAPPI T 414 om-12) brightness (ISO 2469) and opacity (TAPPI T 425 om-96) of handsheets were also investigated.

\subsection{Statistical analysis}

2.4. Statistička analiza

The SPSS 15.0 statistical package was used. Data of chemical, physical and optical properties of the pulp were analyzed using a computerized statistical program to determine variance, and by carrying out the Duncan test at a $P \leq 0.05$ confidence level.

\section{RESULTS AND DISCUSSION}

3. REZULTATI I RASPRAVA

\subsection{Chemical composition and fiber properties}

3.1. Kemijski sastav i svojstva vlakanaca

The chemical composition of the stubble and whole wheat straw used in this study are given in Table
2 with those of some wood species and annual plants. The holocellulose content of stubble was approximately equal to that of hardwood and higher than that of softwood. This is because both stubbles and hardwoods have a higher hemicellulose content and lower lignin content when compared to softwood. The high $\mathrm{NaOH}$ (1 $\%)$ solubility is due to the presence of low molecular weight carbohydrates and other alkali-soluble matters (Tutus and Eroglu, 2003). Also, $\mathrm{NaOH}$ solubility indicates the extent of fiber degradation during the pulping process (Zawawi et al., 2014). Cold water solubility provides a measure of tannins, sugars, gums, and coloring matter. Hot water solubility also removes starches (ASTM, 2013). Because of high silica content, the ash content of the straws was found to be higher than that of other species (Table 2). The holocellulose content of the stubble was higher than that of the whole wheat straw and approximately equal to that of hardwoods.

When compared to previous studies, the results of the chemical analysis show that the stubble was consistent with the literature (Table 2). Only the ash con-

Table 2 Chemical composition and solubility of some annual plants and wood species

Tablica 2. Kemijski sastav i topljivost nekih jednogodišnjih biljaka i vrsta drva

\begin{tabular}{|c|c|c|c|c|c|c|c|c|c|c|}
\hline \multirow[b]{2}{*}{$\begin{array}{l}\text { Annual plants and } \\
\text { wood species } \\
\text { Jednogodišnje biljke } \\
i \text { vrste drva }\end{array}$} & \multicolumn{6}{|c|}{ Chemical composition } & \multicolumn{3}{|c|}{ Solubility } & \multirow[b]{2}{*}{ Literature } \\
\hline & 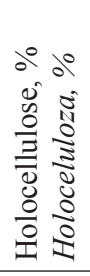 & 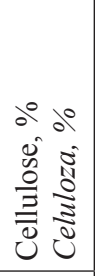 & 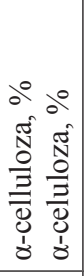 & 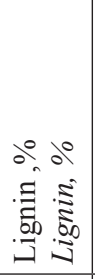 & $\begin{array}{l}00 \\
8 \\
8 \\
2 \\
2 \\
0 \\
0 \\
\frac{0}{2}\end{array}$ & 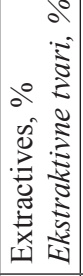 & 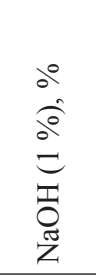 & 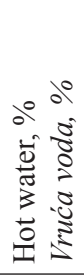 & 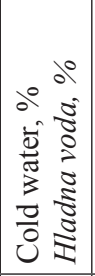 & \\
\hline Stubbles / strnjika & $78^{*}$ & $53 *$ & $40^{\mathrm{ns}}$ & $17 *$ & $7.1^{*}$ & $5.5^{*}$ & $42.1 *$ & $12.9^{*}$ & $8.97 *$ & Current Study \\
\hline $\begin{array}{l}\text { Whole wheat straws } \\
\text { slama pšenice }\end{array}$ & $73 *$ & $51^{*}$ & $39^{\text {ns }}$ & $18^{*}$ & $7.8 *$ & $5.1 *$ & $43.7 *$ & $14.6^{*}$ & $11.5^{*}$ & Current Study \\
\hline A. membranaceus & 77 & 37 & 50 & 24 & 5.5 & 5.6 & 29.4 & 8.4 & 7.20 & Tutus et al., 2014 \\
\hline Papaver somniferum & 80 & 41 & 52 & 19 & 4.7 & - & 30.3 & 10.4 & 5.10 & Tutus et al.,2011 \\
\hline Cotton straw / slama pamuka & 76 & 46 & 40 & 18 & 2.5 & 6.1 & 30.9 & 14.2 & 11.7 & Tutus et al,. 2010 \\
\hline Cotton straw / slama pamuka & 72 & - & 42 & 19 & 2.4 & 6.1 & 42.9 & 17.8 & 16.7 & Akgul, 2007 \\
\hline Cotton carpel / pamuk & 72 & 43 & 31 & 21 & 5.5 & 6.6 & 48.9 & 12.2 & 8.39 & Alma et al., 2005 \\
\hline Wheat straw / slama pšenice & 77 & 52 & 40 & 18 & 7.1 & 5.5 & 40.9 & 12.2 & 7.65 & Tutus 2000 \\
\hline Semen secalis & 74 & 52 & 44 & 15 & 3.2 & 9.2 & 39.2 & 13.0 & 10.2 & Usta and Eroglu, 1987 \\
\hline Corn straw / stabljike kukuruza & 65 & 46 & 36 & 17 & 7.5 & 9.5 & 47.1 & 14.8 & - & Eroglu et al., 1992 \\
\hline Nicotiana tabacum & 68 & - & 38 & 20 & 7.3 & 6.5 & 42.9 & 19.1 & 15.8 & Tank et al., 1985 \\
\hline Lake cane / jezerska trska & 78 & 50 & 48 & 19 & 3.0 & 4.0 & 28.3 & 3.8 & 3.30 & Kirci, 1996 \\
\hline Hibiscus Cannabinus & 81 & 54 & 37 & 15 & 4.1 & 5.0 & 34.9 & 12.8 & 11.7 & Dogan, 1994 \\
\hline Softwoods / meko drvo & $63-74$ & $55-61$ & - & $25-32$ & $0.2-0.5$ & $1-6$ & $8-10$ & $1-5$ & $0.5-4$ & Kirci, 2006 \\
\hline Hardwoods / tvrdo drvo & $72-82$ & $38-55$ & - & $18-26$ & $0.2-0.7$ & $1-6$ & $12-25$ & $1-8$ & $0.2-4$ & Kirci 2006 \\
\hline
\end{tabular}

*Significant at 0.05 level and ${ }^{\text {ns }}$ Non-significant level in Independent Samples T-Test. / *Signifikantno pri razini 0,05 $i{ }^{n s}$ nesignifikantno pri testiranju T-testom 
Table 3 Comparison of fiber parameters of stubbles and whole wheat straws with the parameters of some other fibers (Topcuoglu, 1985; Kırc1, 1996; Alkan et al., 2003, Tutus and Eroglu, 2003, Istek et al., 2008, Tutus et al., 2010, Tutus et al., 2014)

Tablica 3. Usporedba parametara vlakanaca dobivenih od strnjike i slame pšenice s parametrima vlakanaca dobivenih od drugih sirovina (Topcuoglu, 1985.; Kirc1, 1996.; Alkan et al., 2003.; Tutus and Eroglu, 2003.; Istek et al., 2008.; Tutus et al., 2010.; Tutus et al., 2014.)

\begin{tabular}{|l|c|c|c|c|c|}
\hline \multicolumn{1}{|c|}{ Species / Vrsta } & $\begin{array}{c}\text { Felting rate } \\
\text { Brzina filcanja }\end{array}$ & $\begin{array}{c}\text { Elasticity } \\
\text { coefficient } \\
\text { Koeficijent } \\
\text { elastičnosti }\end{array}$ & $\begin{array}{c}\text { Rigidity } \\
\text { coefficient } \\
\text { Koeficijent } \\
\text { krutosti }\end{array}$ & $\begin{array}{c}\text { Runkel index } \\
\text { Runkelov indeks }\end{array}$ & $\begin{array}{c}\text { F factor } \\
\text { F-faktor }\end{array}$ \\
\hline Stubble / strnjika & 60 & 27 & 37 & 2.8 & 16 \\
\hline Whole Wheat Straw / slama pšenice & 62 & 27 & 36 & 2.7 & 17 \\
\hline Crambe orientalis & 24 & 79 & 10 & 0.3 & 23 \\
\hline Crambe tataria & 36 & 70 & 15 & 0.4 & 24 \\
\hline Reed stalks / stabljike trske & 103 & 52 & 24 & 0.9 & 44 \\
\hline Cotton stalks / stabljike pamuka & 33 & 63 & 18 & 0.6 & 29 \\
\hline Sunflower stalks / stabljike suncokreta & 58 & 71 & 15 & 0.4 & 38 \\
\hline Rye straw / slama raži & 38 & 61 & 20 & 0.7 & 22 \\
\hline Tobacco stalks / stabljike duhana & 40 & 29 & 36 & 3.0 & 20 \\
\hline Hardwoods / tvrdo drvo & 45 to 65 & 35 to 65 & 15 to 35 & 0.5 to 2 & 16 to 30 \\
\hline Softwoods / meko drvo & 60 to 80 & 70 to 80 & 15 to 20 & 0.3 to 0.5 & 50 to 60 \\
\hline
\end{tabular}

tent of the stubble was higher than that of softwoods and hardwoods. The oxide-added SOAQ pulping process of wheat straw offers a practical solution to the silica problem that has inhibited the widespread use of cereal straw as a papermaking fiber (Tutus and Eroglu, 2003). This is explained by phytoliths (microfossils of opal silica) formation (Ball et al., 1999; Halvarsson et al., 2010).

The stubble fiber length, fiber width, lumen diameter, and cell wall thickness were found to be 0.894 $\mathrm{mm}, 14.86 \mu \mathrm{m}, 3.94 \mu \mathrm{m}$, and $5.46 \mu \mathrm{m}$, respectively. The respective values for whole wheat straw were $0.876 \mathrm{~mm}, 14.11 \mu \mathrm{m}, 3.79 \mu \mathrm{m}$, and $5.15 \mu \mathrm{m}$. According to that, the fiber dimensions of stubble were similar to those of whole wheat straw. The fiber parameters were also calculated according to the Equations:

Felting power $=$ Fiber length $/$ fiber width

Elasticity coefficient $=$ Lumen diameter $\cdot 100$ / fiber width

Rigidity coefficient $=$ Cell wall thickness $/$ fiber diameter $\cdot 100$

Runkel's classification $=$ Cell wall thickness $\cdot 2$ / lumen diameter

F Factor $=$ Fiber length/cell wall thickness $\cdot 100$

The calculated fiber parameters are given in Table 3 along with the parameters of some other species. Today, as fiber and short fiber pulp concepts are widely used in paper industry, the measurement of fibers constituting pulp and accordingly the relations between pulp properties also become important. For example, increases in fiber length affect strength properties but cause poor paper formation (Kirci, 2006; Akgul and Tozluoglu, 2009).

Felting power is one of the criteria for the suitability of raw material for paper production. This power is important for physical properties of the paper such as breaking length, burst and tear index. It is wanted to be between 70-90 for softwood and 40-60 for hardwood. The felting power of stubble and whole wheat straw was found to be 60.16 and 62.08 , respectively, and to be similar to that of hardwood. The Runkel value is the ratio of fiber cell wall thickness and its lumen and it determines the suitability of a fibrous material for pulp and paper production. If a wood species has a high Runkel value, its fiber will be stiff and less flexible and have poor bonding ability (Kiaei et al., 2014). The Runkel values of the raw materials were higher than those of other species. This means that these raw materials have thick cell walls. The rigidity coefficient of stubble and whole wheat straw were found to be similar to that of hardwoods. This value has a negative effect on tensile, tear, burst and double fold resistance of the paper (Hus et al., 1975).

\subsection{Chemical, physical and optical properties of pulp \\ 3.2. Kemijska, fizikalna i optička svojstva celuloze}

Chemical, physical and optical properties of pulp are given in Table 4 . The pulp was beaten to $50 \pm 3{ }^{\circ} \mathrm{SR}$ in a laboratory beater and test papers were produced with a Rapid Kothen RK-21 paper machine.

According to the same Table 4, 7 bars is the most appropriate value of oxygen pressure. The increase of oxygen pressure during the cooking process has a positive effect on the kappa number, pulp viscosity and DP, breaking length, tear index, and brightness value. The oxygen pressure of 7 bars should be used in other studies related to the same subject. In Table 4, the optimal value of $\mathrm{NaBH}_{4}$ was determined as $0.3 \%$ and 0.5 $\%$. However, considering the economic importance of using the Soda-Oxygen- $\mathrm{NaBH}_{4}$ method for the pulp production, the most appropriate ratio of $\mathrm{NaBH}_{4}$ was accepted as $0.3 \%$. The increase of the $\mathrm{NaBH}_{4}$ ratio during the cooking process has a positive effect on the pulp yield, kappa number, pulp viscosity and DP, tear 


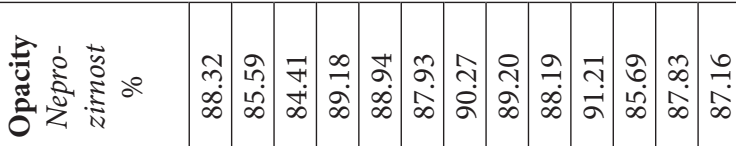

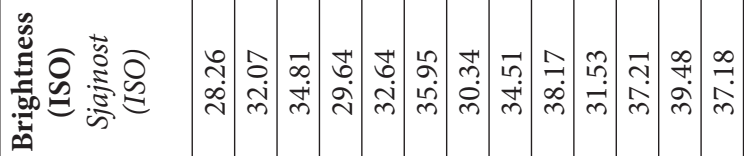

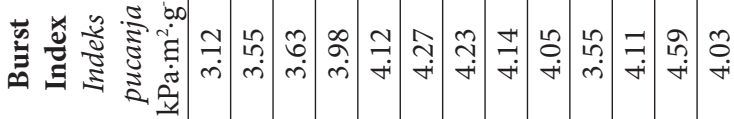

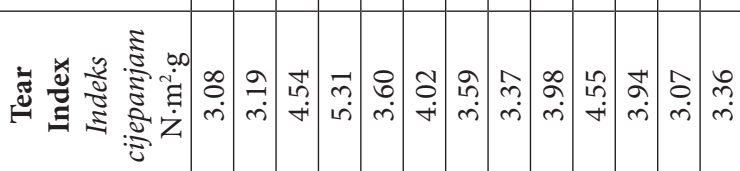

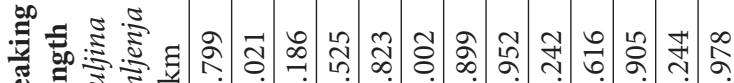

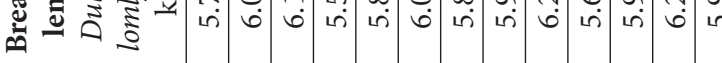

å $\quad$ 守

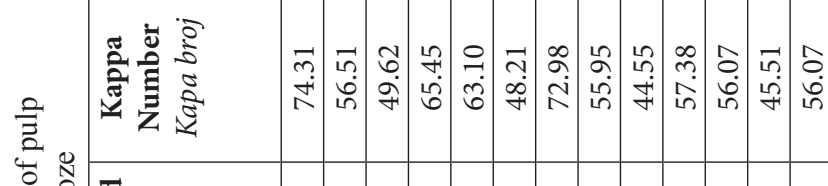

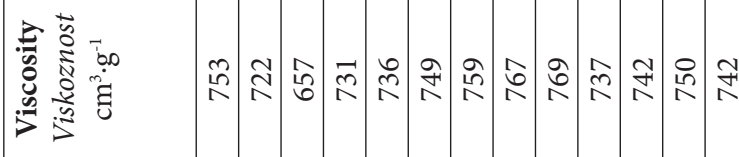

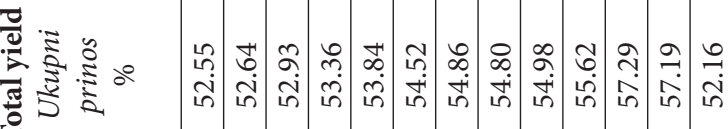

吾

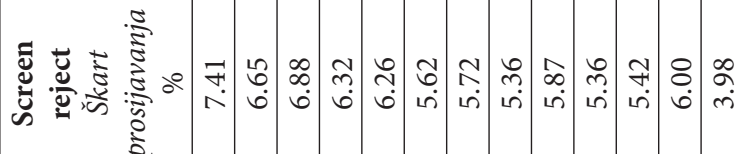

苟

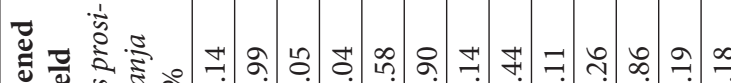

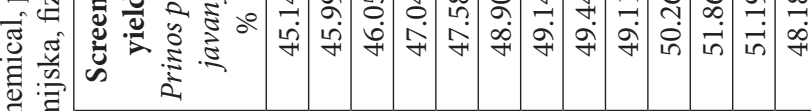

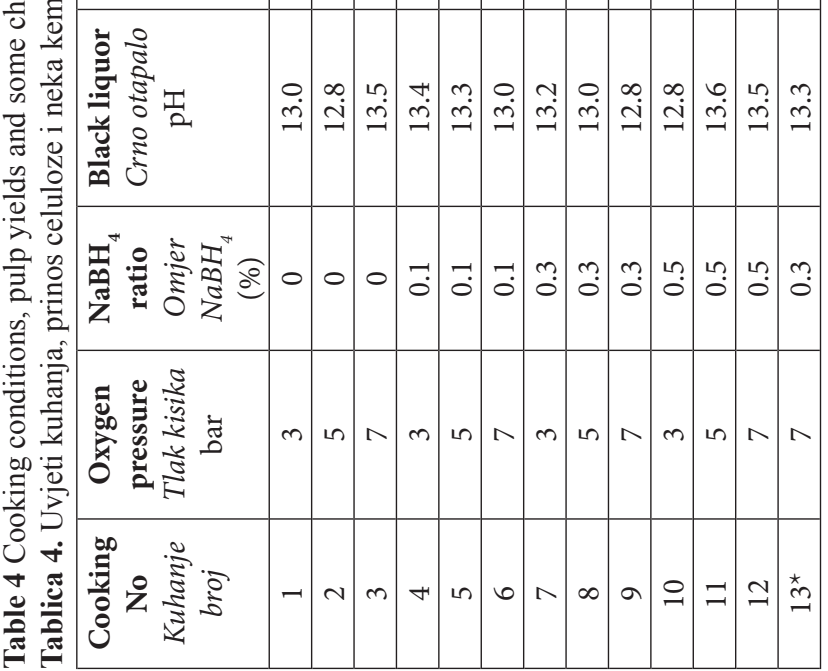



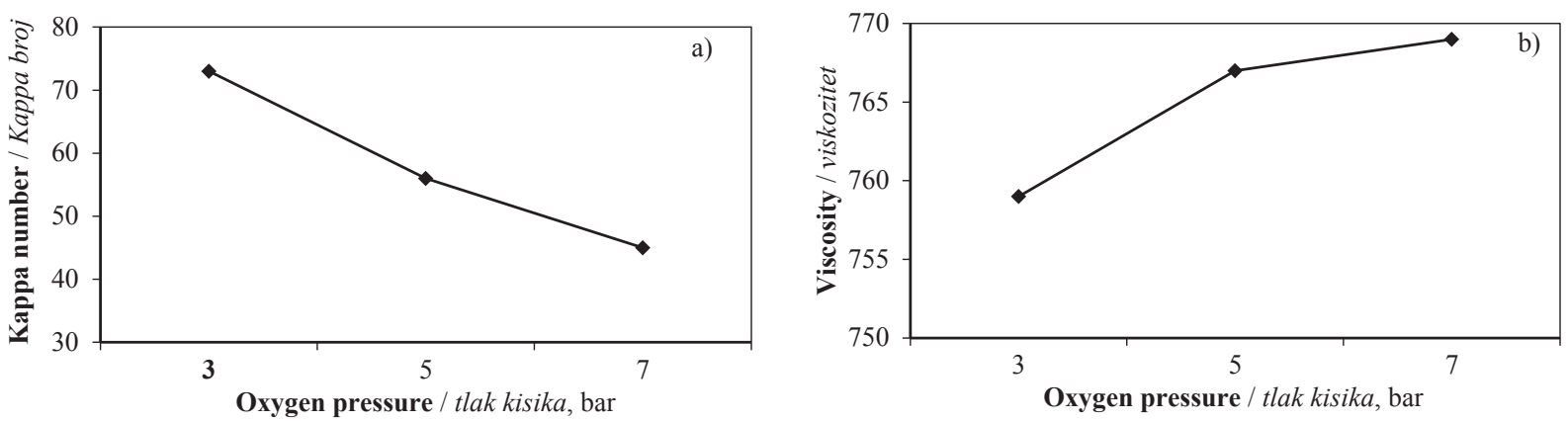

Figure 1 Effects of oxygen pressure on kappa number (a) and viscosity (b)

Slika 1. Utjecaj tlaka kisika na (a) kapa broj i (b) na viskoznost

Table 5 Effects of oxygen pressure on chemical, physical, and optical properties of the stubble pulp

Tablica 5. Utjecaj tlaka kisika na kemijska, fizikalna i optička svojstva celuloze proizvedene od strnjike pšenice

\begin{tabular}{|c|c|c|c|c|c|c|c|c|}
\hline $\begin{array}{c}\text { Oxygen } \\
\text { pressure } \\
\text { Tlak kisika } \\
\text { bar }\end{array}$ & $\begin{array}{c}\text { Yield } \\
\text { Prinos } \\
\%\end{array}$ & $\begin{array}{c}\text { Kappa No } \\
\text { Kapa broj }\end{array}$ & $\begin{array}{c}\text { Viscosity } \\
\text { Viskoznost } \\
\mathrm{cm}^{3} \cdot \mathrm{g}^{-1}\end{array}$ & $\begin{array}{c}\text { Breaking } \\
\text { length } \\
\text { Duljina } \\
\text { lomljenja } \\
\mathrm{km}\end{array}$ & $\begin{array}{c}\text { Tear } \\
\text { Index } \\
\text { Indeks } \\
\text { cijepanjam } \\
\mathrm{N} \cdot \mathrm{m}^{2} \cdot \mathrm{g}\end{array}$ & $\begin{array}{c}\text { Burst } \\
\text { Index } \\
\text { Indeks } \\
\text { pucanja } \\
\mathrm{kPa} \cdot \mathrm{m}^{2} \cdot \mathrm{g}^{-1}\end{array}$ & $\begin{array}{c}\text { Brightness } \\
\text { (ISO) } \\
\text { Sjajnost } \\
(\text { ISO) }\end{array}$ & $\begin{array}{c}\text { Opacity } \\
\text { Neprozirnost } \\
\%\end{array}$ \\
\hline 3 & 54.86 & $73 \mathrm{c}$ & $759 \mathrm{a}$ & $5.90 \mathrm{a}$ & $4.05 \mathrm{a}$ & $3.59 \mathrm{~b}$ & $30.34 \mathrm{a}$ & $90.27 \mathrm{~b}$ \\
\hline 5 & 54.80 & $56 \mathrm{~b}$ & $767 \mathrm{a}$ & $5.95 \mathrm{a}$ & $4.14 \mathrm{a}$ & $3.37 \mathrm{a}$ & $34.52 \mathrm{~b}$ & $89.20 \mathrm{a}$ \\
\hline 7 & 54.98 & $45 \mathrm{a}$ & $769 \mathrm{a}$ & $6.24 \mathrm{~b}$ & $4.23 \mathrm{a}$ & $3.98 \mathrm{c}$ & $38.17 \mathrm{c}$ & $88.19 \mathrm{a}$ \\
\hline
\end{tabular}

* $\mathrm{NaBH}_{4}$ charge was kept $0.3 \%$ and mean values with the same lower-case letters are not significantly different according to Duncan's mean separation test. / Udjel $\mathrm{NaBH}_{4}$ bio je 0,3\%, a srednje vrijednosti s istim slovom nisu signifikantno različite prema Duncanovu testu.

index, and burst index. Variance analysis and Duncan test were performed using these data

Increasing the oxygen pressure decreases the kappa number (Figure 1a) and increases viscosity (Figure 1b), breaking length, burst index, tear index, and brightness (Table 5). In our experiments, the yield was independent of oxygen pressure (Table 5). However, for experiments using wheat straw over a greater range of oxygen pressure (6-14 bar), the yield was lowered by approximately $1 \%$ at the highest pressure (Deniz, 1994; Tutus, 2000).

The lower kappa number at higher oxygen pressure is consistent with other experiments using wheat straws (Tutus, 2000).

\subsection{Effect of $\mathrm{NaBH}_{4}$ on pulp physical, optical and} chemical properties

3.3. Utjecaj $\mathrm{NaBH}_{4}$ na fizikalna, optička i kemijska svojstva celuloze

The pulping additive $\mathrm{NaBH}_{4}$ acts as a catalyst by protecting the end groups from a peeling reaction, which increases the screened pulp yield (Istek and Ozkan, 2008).

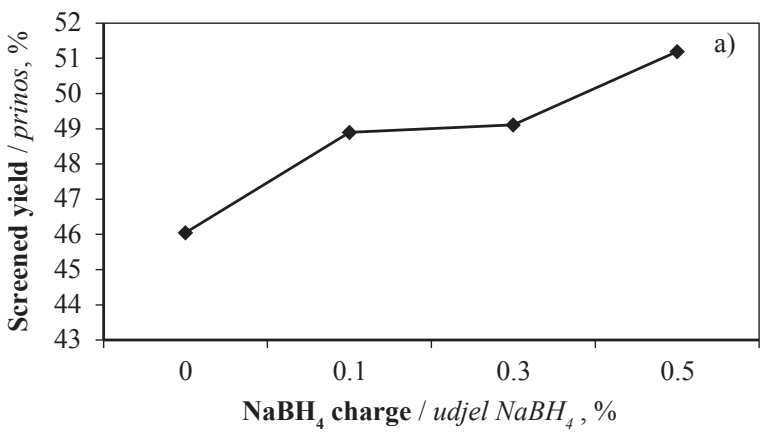

Figure 2 Effects of $\mathrm{NaBH}_{4}$ charge on screened yield (a) and viscosity (b)

Slika 2. Utjecaj udjela $\mathrm{NaBH}_{4}$ na (a) prinos prosijavanja i (b) na viskoznost

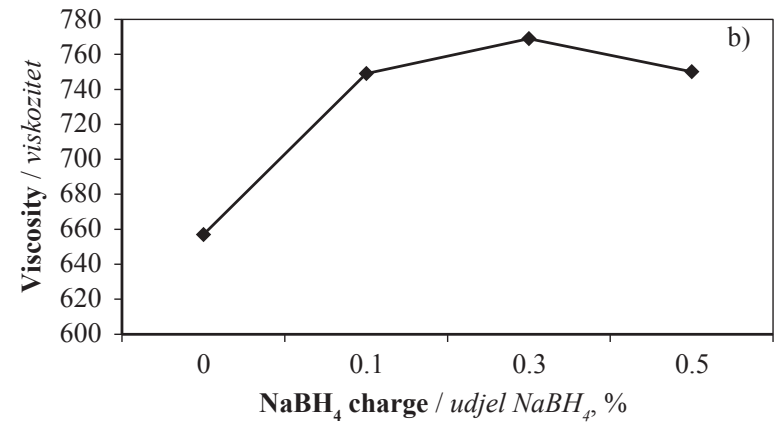
creened yield and viscosity. Adding of $\mathrm{NaBH}_{4}$ increased screened yield (Figure $2 \mathrm{a}$ ) and viscosity (Figure $2 b$ ) and DP (Table 4).

Other kraft- $\mathrm{NaBH}_{4}$ studies of Eucalyptus grandis (Ayata, 2008) and red pine wood (Temiz, 2006) have shown a decrease in kappa number with the addition of $\mathrm{NaBH}_{4}$. Yield increases have been observed when adding $\mathrm{NaBH}_{4}$ to cooking solution during pulp production (Petterson and Rydholm, 1961; Tutus and Alma, 2005) and soda-oxygen cooking (Hafizoglu, 1982; Tutus, 2004).

$\mathrm{NaBH}_{4}$ content, which has an important effect on the soda-oxygen- $\mathrm{NaBH}_{4}$ cooking, the obtained pulp yield at various oxygen pressure, and the summary of the Duncan tests, which was done with some chemical properties and important physical and optical properties, are given in Table 6.

It was established that the most appropriate oxygen pressure was 7 bars. While the increase of oxygen pressure during the cooking process has a positive effect on the kappa number, pulp viscosity and DP, 
Table 6 Effects of $\mathrm{NaBH}_{4}$ on chemical, physical, and optical properties of the stubble pulp

Tablica 6. Utjecaj udjela $\mathrm{NaBH}_{4}$ na kemijska, fizikalna i optička svojstva celuloze proizvedene od strnjike pšenice

\begin{tabular}{|c|c|c|c|c|c|c|c|c|}
\hline $\begin{array}{c}\mathrm{NaBH}_{4} \\
\text { charge } \\
\text { Udjel } \\
\mathrm{NaBH}_{4}\end{array}$ & $\begin{array}{c}\text { Yield } \\
\text { Pri- } \\
\text { nos } \\
\%\end{array}$ & $\begin{array}{l}\text { Kappa } \\
\text { No } \\
\text { Kapa } \\
\text { broj }\end{array}$ & $\begin{array}{l}\text { Viscosity } \\
\text { Viskoznost } \\
\mathrm{cm}^{3} \cdot \mathrm{g}^{-1}\end{array}$ & $\begin{array}{c}\text { Breaking length } \\
\text { Duljina } \\
\text { lomljenja } \\
\mathrm{km}\end{array}$ & $\begin{array}{c}\text { Tear } \\
\text { Index } \\
\text { Indeks cijepanja } \\
\mathrm{mN} \cdot \mathrm{m}^{2} \cdot \mathrm{g}\end{array}$ & $\begin{array}{c}\text { Burst } \\
\text { Index } \\
\text { Indeks pucanja } \\
\mathrm{kPa} \cdot \mathrm{m}^{2} \cdot \mathrm{g}^{-1}\end{array}$ & $\begin{array}{c}\text { Brightness } \\
\text { (ISO) } \\
\text { Sjajnost } \\
\text { (ISO) }\end{array}$ & $\begin{array}{c}\text { Opacity } \\
\text { Nepro- } \\
\text { zirnost } \\
\%\end{array}$ \\
\hline 0 & 52.9 & $50 \mathrm{c}$ & $657 \mathrm{c}$ & $6.2 \mathrm{a}$ & $3.6 \mathrm{c}$ & $4.5 \mathrm{a}$ & $34.8 \mathrm{~b}$ & $84.4 \mathrm{~b}$ \\
\hline 0.1 & 54.5 & $48 b$ & $749 \mathrm{~b}$ & $6.0 \mathrm{~b}$ & $4.1 \mathrm{~b}$ & $4.0 \mathrm{~b}$ & $35.9 b$ & $87.9 a$ \\
\hline 0.3 & 54.9 & $45 \mathrm{a}$ & $769 \mathrm{a}$ & $6.2 \mathrm{a}$ & $4.0 \mathrm{~b}$ & $3.9 \mathrm{~b}$ & $38.1 \mathrm{a}$ & $88.1 \mathrm{a}$ \\
\hline 0.5 & 57.2 & $46 \mathrm{~b}$ & $750 \mathrm{~b}$ & $6.2 a$ & $4.6 \mathrm{a}$ & $3.1 \mathrm{c}$ & $39.5 \mathrm{a}$ & $87.8 \mathrm{a}$ \\
\hline
\end{tabular}

*Oxygen pressure was kept at 7 bars and mean values with the same lower-case letters are not significantly different according to Duncan's mean separation test. / Tlak kisika bio je 7 bara, a srednje vrijednosti s istim slovom nisu signifikantno različite prema Duncanovu testu.

breaking length, tear index and brightness value, it also has a negative effect on the other chemical, physical and optic properties. The oxygen pressure of 7 bars should also be used for the other studies related to the same subject.

\section{CONCLUSION}

4. ZAKLJUČAK

The optimal cooking conditions for the chemical, physical and optical properties during the pulp production with soda-oxygen- $\mathrm{NaBH}_{4}$ method is presented in Table 7 below.

Consequently, the following advantages could be obtained by using stubbles and $\mathrm{NaBH}_{4}$ for pulp and paper production:

1. Pulp made from stubble has properties similar to those made from whole wheat straw pulp;

2. Harvesting of stubble would increase the availability of fiber in countries such as Turkey where wood resources are limited;

3. The addition of $\mathrm{NaBH}_{4}$ protects the reducing end groups from peeling reaction and increases screened pulp yield;

4. Pulp made with the addition of $\mathrm{NaBH}_{4}$ have higher brightness and are easier to bleach but have lower opacity;

5. Turkey has 73 percent of boron reserves in the world, which makes $\mathrm{NaBH}_{4}$ an attractive additive in this region.

Table 7 The optimal cooking conditions during pulp production with soda-oxygen- $\mathrm{NaBH}_{4}$ method

Tablica 7. Optimalni uvjeti kuhanja pri proizvodnji celuloze metodom kuhanja s dodatkom soda-kisik-natrijborohidrida

\begin{tabular}{|l|c|c|}
\hline \multicolumn{1}{|c|}{$\begin{array}{c}\text { Pulping conditions } \\
\text { Uvjeti kuhanja }\end{array}$} & $\begin{array}{c}\text { Unit } \\
\text { Jedinica }\end{array}$ & $\begin{array}{c}\text { Value } \\
\text { Vrijednost }\end{array}$ \\
\hline $\mathrm{NaOH}$ charge / udjel $\mathrm{NaOH}$ & $\%$ & 16 \\
\hline $\mathrm{NaBH}_{4}$ charge / udjel $\mathrm{NaBH}_{4}$ & $\%$ & 0.3 \\
\hline Oxygen pressure / tlak kisika & bar & 7 \\
\hline $\begin{array}{l}\text { Cooking temperature } \\
\text { temperatura kuhanja }\end{array}$ & ${ }^{\circ} \mathrm{C}$ & 140 \\
\hline $\begin{array}{l}\text { Time to maximum temperature } \\
\text { vrijeme do postizanja maksimalne } \\
\text { temperature }\end{array}$ & Min & 40 \\
\hline $\begin{array}{l}\text { Time at maximum temperature } \\
\text { vrijeme pri maksimalnoj temperaturi }\end{array}$ & Min & 50 \\
\hline $\begin{array}{l}\text { Liquor to raw material ratio } \\
\text { omjer otapala i sirovine }\end{array}$ & $\mathrm{L} / \mathrm{kg}$ & $5 / 1$ \\
\hline
\end{tabular}

Acknowledgement - Zahvala

This research was supported by the Kahramanmaras Sutcu Imam University, Research Project Coordination Unit, under project number 2011/7-14 YLS.

\section{REFERENCES}

\section{LITERATURA}

1. Akgul, M., 2007: Determination of the pulp and paper production conditions with soda-alcohol, soda-AQ, soda-alcohol-AQ methods from cotton straw (Gossypium hirsutum L.). Presidency of Scientific Research Projects, SRP Project Code Number: 2005.05.03.221, Düzce-Turkey.

2. Akgul, M.; Tozluoglu, A., 2009: Some chemical and morphological properties of juvenile woods from beech (Fagus orientalis L.) and pine (Pinus nigra A.) plantations. Trends in Applied Sciences Research, 4 (2): 116125. http://dx.doi.org/10.3923/tasr.2009.116.125.

3. Aksoy, H. G.; Birbilen, Y.; Karakuş, K.; Basboga, I. B.; Mengeloglu, F., 2014: Some mechanical properties of polyvinyl alcohol (PVA) based biodegradable composites, $3^{\text {rd }}$ International Non-wood Forest Products Symposium, 472-477, 8-10 May, Kahramanmaraş, Turkey.

4. Alkan, C.; Eroglu, H.; Yaman, B., 2003: Fiber morphology of some woody angiospermae taxon in Turkey. Zonguldak Karaelmas University, Journal of Bartin Faculty of Forestry, 5 (5): 102-108.

5. Alma, M. H.; Kalaycioglu, H.; Bektas, İ.; Tutus, A., 2005: Properties of cotton carpel-based particleboards. Industrial Crops and Products, 22: 141-149. http://dx.doi.org/10.1016/j.indcrop.2004.08.001.

6. Tappi, 1992: TAPPI test methods, standard methods for pulp and paper, technical association of pulp and paper industry. Tappi Press, Atlanta.

7. ASTM D 1107-96. 1998. Standard test method for ethanol-toluene solubility of wood. ASTM International, West Conshohocken, PA.

8. ASTM D 1110-84. 2013. Standard test methods for water solubility of wood. ASTM International, West Conshohocken, PA.

9. Ayata, U., 2008: Wood features of eucalyptus (Eucalyptus camaldulensis ve Eucalyptus grandis) and research of its use in paper industry. Master's Thesis, KSU, Institute of Science, Kahramanmaraş-Turkey.

10. Ball, T. B.; Gardner, J. S.; Anderson, N., 1999: Identifying inflorescence phytoliths from selected species of wheat (Triticum monococcum, T. dicoccon, T. dicoccoides, and T. aestivum) and barley (Hordeum vulgare and H. spontaneum) (Gramineae). American Journal of Botany, 86(11):1615-1623.http://dx.doi.org/10.2307/2656798

11. Beg, M. D. H.; Pickering, K. L., 2008: Mechanical performance of Kraft fibre reinforced polypropylene composites: Influence of fibre length, fibre beating and hy- 
grothermal ageing. Composites: Part A, Applied Science and Manufacturing, 39: 1748-1755.

http://dx.doi.org/10.1016/j.compositesa.2008.08.003.

12. Chandra, M., 1998: Use of nonwood plant fibers for pulp and paper industry in Asia: Potential in China. Master's Thesis, Virginia Polytechnic Institute and State University, Blacksburg, Virginia.

13. Cheng, Z., 1993: Recent developments in China pulp and paper research on wheat straw, straw - a valuable raw material. April, London, Pira International, Paper, No. 18.

14. Deniz, I., 1994: Predesilication of wheat (Triticum aestivum L.) straw and the action of this pretreatment on $\mathrm{O}_{2}$ $\mathrm{NaOH}$ pulping conditions. Ph.D. Thesis, K. T. U, Institute of Science, Trabzon-Turkey.

15. Diaz, M. J.; Garcia, M. M.; Eugenio, M. E.; Tapias, R.; Fernandez, M.; Lopez, F., 2007: Variations in fiber length and some pulp chemical properties of Leucaena varieties. Industrial Crops and Products, 26 (2): 142-150. http://dx.doi.org/10.1016/j.indcrop.2007.02.003.

16. Dogan, H., 1994: Kenaf studies in SEKA. Journal of Seka, 50: 18-22.

17. Eroglu, H., 1983: Soda-Oxygen pulping of wheat straw. Nonwood Plant Fiber Pulping Conference. Houston, Tappi Press, Progress Report No.14: 99-106.

18. Eroglu, H.; Usta, M.; Kirci, H., 1992: A Review of oxygen pulping conditions of some non-wood plant growing in Turkey. Tappi Pulping Conference, 215-222.

19. Faostat, 2015: Food and Agriculture Organization of the United Nations website, http://faostat.fao.org/site/567/ default.aspx\#ancor: 30.12.2015.

20. Gençer, A., 2015: The utilization of kiwi (Actinidia deliciosa) pruning waste for kraft paper production and the effect of the bark on paper properties. Drewno, vol. 58, No. 194: 103-113, 2015. http://dx.doi.org/10.12841/wood.1644-3985.084.08.

21. Hafizoglu, H., 1982: Chemistry of Forest Products. KTU Faculty of Forestry, 52: 100-101. KTU Printing House, Trabzon-Turkey.

22. Halvarsson, S.; Edlund, H.; Norgren, M., 2010: Wheat straw as raw material for manufacture of MDF. BioResources, 5 (2): 1215-1231.

23. Hus, S.; Tank, T.; Goksal, E., 1975: Considering eucalyptus (E. Camadulensis Dhnh) wood which grow in Turkey (in Tarsus-Karabacak), Morphology and opportunity for evaluating semi chemical cellulose in paper industry. Tubitak Publication, USA.

24. ISO 2469:2014: Paper, board and pulps, Measurement of diffuse radiance factor (diffuse reflectance factor).

25. ISO 5269/2, 2004: Pulp - Preparation of laboratory sheets for physical testing, Part 2: RapidKöthen method.

26. Istas, J. R., 1954: Hsremans R. and Roekelboom, E. L. INEAC Serie, Tecknique, No. 43/9.

27. Istek, A.; Ozkan, I., 2008: Effect of sodium borohydride on Populus tremula L. Kraft Pulping. Turkish Journal of Agriculture And Forestry, 32 (2): 131-136.

28. Istek, A.; Tutus, A.; Gulsoy, S. K., 2009: The effect of tree age on fiber morphology of Pinus pinaster and paper properties. KSU Journal of Engineering Sciences, 12 (1): $1-5$.

29. Kara, O.; Bolat, I., 2009: Ecological Indicators, 9: 11511155. http://dx.doi.org/10.1016/j.ecolind.2009.01.002

30. Kiaei, M.; Tajik, M.; Vaysi, R., 2014: Chemical and biometrical properties of plum wood and its application in pulp and paper production. Maderas. Ciencia y tecnología 16 (3): 313-322. http://dx.doi.org/10.4067/S0718221X2014005000024.

31. Kirci, H., 1996: Determination of pulping conditions of Phragmites communis L. with soda-oxygen method.
Karadeniz Technical University, Fund Research, No. 95.113.002.6, Trabzon-Turkey.

32. Kirci, H., 2006: Pulp Industry Lecture Notes. Karadeniz Technical University, Forest Faculty Publication, Trabzon-Turkey.

33. Kurschner, K.; Hoffer, A., 1993: Cellulose and cellulose derivatives. Fresenius Journal of Analytical Chemistry, 92 (3): 145-154.

34. Madsen, B.; Gamstedt, E. K., 2013: Wood versus Plant Fibers: Similarities and differences in composite applications, Advences in Material Science and Engineering, 2013: 1-14. http://dx.doi.org/10.1155/2013/564346.

35. Paul, E. A.; Clark, F. E., 1989: Soil Microbiology and Biochemistry. Academic Press, Elsevier Science.

36. Petterson, S. E.; Rydholm, S. A., 1961: Hemicelluloses and paper properties of Birch pulps, Part 3. Svensk Papperstiding, 64 (1): 4-17.

37. Sahinbas, Y., 2015: "Stubble Burn, Future Burn" (online). http://www.iskilipliyiz.com/genel-haberleri-anizyakmanin-zararlari-nelerdir-2061.html. First published 2011 (Accessed Dec. 26, 2015).

38. Tank, T.; Bostanci, S.; Eroglu, E.; Enercan, S., 1985: Paper production from tobacco stalks. J. Natural Sci., D2, 9, 3.

39. Temiz, S., 2006: Determination of $\mathrm{Kraft}^{-\mathrm{NaBH}_{4}}$ pulping condition of Uludağ Fir (Abies bornmuelleriana Mattf.) and Red Pine (Pinus brutia ten.). Master's Thesis, Abant İzzet Baysal University, Institute of Science, Düzce-Turkey.

40. Thumn, A.; Dickson, A. R., 2013: The influence of fibre length and damage on the mechanical performance of polypropylene/wood pulp composites. Composites Part A: Applied Science and Manufacturing, 46: 45-52.

http://dx.doi.org/10.1016/j.compositesa.2012.10.009.

41. Topcuoglu, M., 1985: Internal Morphology Studies of Spruce (Picea orientalis) on Wood. Ormanc1lık Araştırma Enstitüsü Yayınları, Technical Bulletin, No. 134, AnkaraTurkey.

42. Tutus A.; Ezici, A. C.; Ates, S., 2010: Chemical, morphological and anatomical properties and evaluation of cotton stalks (Gossypium hirsutum L.) in pulp industry. Scientific Research and Essays, 5 (12): 1553-1560.

43. Tutus, A., 2000: The investigation of soda-oxygen, sodaanthraquinone and soda methods used in pulp production from wheat (Triticum aestivum L.) straw on the problem of silica and other aspects. Ph.D Thesis, Zonguldak Karaelmas University, Institute of Science, Bartın-Turkey.

44. Tutus, A., 2004: Bleaching of wheat straw SOAQ pulps with Hydrojen Peroxide and Sodium Borohydride. Proceedings of the 2nd International Boron Symposium, 345-350, Eskişehir-Turkey.

45. Tutus, A.; Alma, M. H., 2005: The use of boron compounds in pulp production and bleaching. I. National Boron Workshop, Proceeding, pp. 399, Ankara-Turkey.

46. Tutus, A.; Cicekler, M.; Karatas, B., 2011: Pulp and paper production by Kraft-Sodium Borohydride method from Poppy Stems. II. International Non-Wood Forest Products Symposium, 183-190, Isparta/Turkey. http:// dx.doi.org/10.13140/2.1.4052.3201.

47. Tutus, A.; Cicekler, M.; Ozdemir, F.; Yilmaz, U., 2014: Evaluation of Diospyros kaki grown in Kahramanmaraş in pulp and paper production. II. National Mediterranean Forest and Environment Symposium, 775-784, IspartaTurkey. http://dx.doi.org/10.13140/2.1.1774.9441.

48. Tutus, A.; Eroglu, H., 2003: A practical solution to silica problem in straw pulping. APPITA Journal, 56 (2): 111115, Australia.

49. Tutus, A.; Kirci, H.; Alma, M. H.; Deniz, İ.; Karademir, A., 2009: Pulp production with kraft-sodium borohy- 
......... Tutuş, Çiçekler: Evaluation of Common Wheat Stubbles (Triticum aestivum L.)...

dride method from wheat straw and bleaching with oxygen-sodium perborate monohydrate. Research Project, Final Report, Project Number: Boren-2006-Ç-01, National Boron Research Institute, Ankara-Turkey.

50. Usta, M.; Eroglu, H., 1987: Soda-Oxygen pulping of rye straw. Nonwood Plant Fiber Pulping Conference, Tappi Press, Progress Report, 18, 113-118, Washington.

51. Yasar, S.; Boselli, E.; Turan, R.; Cicekler, M., 2016. Viscous gel-forming gums (VGUMS) of cereal grains: Rheology and viscosity-based enzyme activity quantification. Journal of Cereal Science, 69 (1): 151-157. http:// dx.doi.org/10.1016/j.jcs.2016.03.003.

52. Zawawi, D.; Mohd, Z. M. H.; Angzzas, S. M. K.; Halizah, A.; Ashuvila, M. A., 2014: Exploring of agro waste (pineapple leaf, corn stalk and napier grass) by chemical composition and morphological study. BioResources, 9 (1): $872-880$.

http://dx.doi.org/10.15376/biores.9.1.872-880.

\section{Corresponding address:}

MUSTAFA ÇIÇEKLER, Ph.D.

Department of Forest Industry Engineering Faculty of Forestry

Kahramanmaras Sutcu Imam University 46100 Kahramanmaras, TURKEY

e-mail: mcicekler@ksu.edu.tr 